\begin{tabular}{|l|l|r|}
\hline Al Fitrah & Pengaruh Permainan Puzzle \\
\hline Journal Of Early Childhood Islamic Education & Magneticeria Terhadap Kecerdasan \\
ISSN : 2599-2287 E-ISSN : 2622-335X & Koordinasi Gerakan Tubuh... \\
Vol.3 No.1Juli 2019 & Sinta Agusmiati \\
\hline
\end{tabular}

\title{
PENGARUH PERMAINAN PUZZLE MAGNETICERIA TERHADAP KECERDASAN KOORDINASI GERAKAN TUBUH DAN MOTORIK ANAK DI PAUD KARYA GALANG SELEBAR KOTA BENGKULU
}

\begin{abstract}
Abstrak
Tujuan dari penelitian ini adalah untuk mengetahui pengaruh permainan puzzle magneticeria terhadap kecerdasan koordinasi gerakan tubuh dan motorik anak di PAUD Karya Galang Selebar Kota Bengkulu. Penelitian ini merupakan penelitian pre-eksperimental design, yaitu salah satu bentuk desain eksperimen, dengan jumlah subjek 14 orang anak kelas B. Hasil penelitian menunjukkan bahwa Berdasarkan harga zhitung= 0,28, maka harga ztabel adalah 0,3897. Harga ini ternyata lebih besar dari harga $\alpha$ yang ditetapkan $5 \%$ atau $0,05(0,3897>0,05)$. Hal ini berarti Ha diterima dan Ho ditolak, artinya terdapat pengaruh permainan puzzle magneticeria terhadap kecerdasan koordinasi gerakan tubuh dan motorik anak di PAUD Karya Galang Selebar Kota Bengkulu.
\end{abstract}

Kata Kunci: Permainan Puzzle Magneticeria, Kecerdasan Koordinasi Gerakan Tubuh dan Motorik Anak.

\begin{abstract}
The purpose of this study was to determine the effect of magneticeria puzzle game on the intelligence of children's body and motor movement coordination in PAUD Karya Galang Selebar Kota Bengkulu. This research is a pre-experimental design, which is one form of experimental design, with the number of subjects 14 children of class $B$. The results of the study show that Based on the price of zcount $=0.28$, the price of ztable is 0.3897 . This price turns out to be greater than the price $\alpha$ which is set at $5 \%$ or 0.05 (0.3897>0.05). This means that Ha is accepted and Ho is rejected, meaning that there is the influence of the magneticeria puzzle game on the intelligence of children's body and motor movement coordination in PAUD Karya Galang Selebar Bengkulu City.
\end{abstract}

Keywords: Puzzle Magneticeria Games, Children's Bodily-Kinesthetic Intelligences

\author{
Sinta Agusmiati \\ sinta.agustimiati@gmail.com \\ Program Studi Pendidikan Islam \\ Anak Usia Dini (PIAUD) \\ Fakultas Tarbiyah dan Tadris \\ IAIN Bengkulu
}

\section{PENDAHULUAN}

Pendidikan Anak Usia Dini adalah suatu usaha pembinaan yang ditujukan kepada anak sejak lahir sampai dengan usia enam tahun yang dilakukan melalui pemberian rangsangan pendidikan untuk membantu pertumbuhan dan perkembangan jasmani dan rohani agar anak memiliki 


\begin{tabular}{|l|l|r|}
\hline & Al Fitrah & Pengaruh Permainan Puzzle \\
Journal Of Early Childhood Islamic Education & Magneticeria Terhadap Kecerdasan \\
ISSN : 2599-2287 E-ISSN : 2622-335X & Koordinasi Gerakan Tubuh... \\
Vol.3 No.1Juli 2019 & Sinta Agusmiati \\
\hline
\end{tabular}

kesiapan dalam memasuki pendidikan lebih lanjut. ${ }^{1}$

Anak usia dini adalah anak yang baru dilahirkan sampai usia 6 tahun, merupakan usia yang sangat menentukan dalam pembentukan karakter dan kepribadian anak, usia dini merupakan usia yang mana anak mengalami pertumbuhan dan perkembangan yang pesat, disebut usia emas (golden age), makanan bergizi seimbang serta asupan yang terus menerus sangat dibutuhkan untuk tumbuh kembang anak. $^{2}$

Berdasarkan tinjauan secara psikologi dan ilmu pendidikan, masa usia dini merupakan masa peletak dasar atau fondasi awal bagi pertumbuhan dan perkembangan anak, yang diterima anak pada masa usia dini, baik itu makanan, minuman, serta stimulasi dari lingkungannya memberikan kontribusi yang sangat besar pada pertumbuhan dan perkembangan anak pada masa itu dan berpengaruh besar pertumbuhan serta perkembangan selanjutnya. $^{3}$

Hal inilah yang menjadi kewajiban pemerintah untuk melaksanakan pendidikan anak usia dini, karena sangat penting untuk masa depan anak bangsa. Tujuan dari diselenggarakannya PAUD, yaitu secara umum adalah mengembangkan berbagai potensi anak sejak dini sebagai persiapan untuk hidup dan dapat menyesuaikan diri dengan lingkungannya, dengan tujuan utama ialah untuk membentuk anak Indonesia yang berkualitas, yaitu anak yang tumbuh dan berkembang sesuai dengan tingkat perkembangannya sehingga memiliki kesiapan yang optimal di dalam memasuki pendidikan dasar serta mengarungi kehidupan di masa dewasa, juga tujuan penyerta membantu menyiapkan anak mencapai hasil belajar akademik di sekolah. ${ }^{4}$ Tujuan khusus yang

${ }^{1}$ Tim Redaksi Pustaka Yustisia, Perundangan tentang Kurikulum Sistem Pendidikan Nasional 2013, h. 3.

${ }^{2}$ Yuliani Nurani Sujiono, Konsep Dasar Pendidikan Anak Usia Dini (Jakarta: Indeks, 2009), h. 7.

${ }^{3}$ Yuliani Nurani Sujiono, Konsep Dasar Pendidikan Anak Usia Dini, h. 10.

${ }^{4}$ Novan Ardy Wiyani, Konsep Dasar PAUD (Yogyakarta: Gava Media, 2016), h. 10. ingin dicapai adalah mengidentifikasi perkembangan tubuh anak dan mengaplikasikan hasilnya dalam pengembangan fisik anak itu; paham perkembangan kreativitas anak dan cara yang terkait dengan pengembangannya; memahami kecerdasan jamak dan kaitannya dengan perkembangan anak; mengerti arti bermain untuk perkembangan anak; memahami pendekatan pembelajaran dan penerapannya; membantu kesiapan anak belajar di sekolah; campur tangan guru da orang tua memberikan stimulasi hingga dapat menumbuhkan bakat yang tersembunyi (hidden potency) yaitu perkembangan anak (bahasa, emosi, sosial, motorik, konsep diri, minat dan bakat); melakukan deteksi dini terhadap kemungkinan terjadinya gangguan dalam pertumbuhan dan perkembangan potensi-potensi yang dimiliki anak. ${ }^{5}$

\section{Kecerdasan Koordinasi Gerakan Tubuh dan Motorik}

Kecepatan koordinasi gerakan tubuh dan motorik atau dapat disebut kecerdasan kinestetik atau gerak motorik merupakan salah satu bagian dari multiple intelligences yang berkaitan dengan kepekaan dan keterampilan dalam mengontrol koordinasi gerakan tubuh melalui gerakan motorik kasar dan halus, seperti menggunakan alat-alat secara terampil, melompat, berlari, berhenti secara tiba-tiba dengan terampil dalam melakukan gerakan senam, menari, silat, dan lain-lain. Kecerdasan ini juga mencakup keterampilan tubuh khusus, seperti koordinasi, kesimbangan, kekuatan, fleksibiltas, kecepatan, taktil, dan haptik. Perkembangan kecerdasan dalam mengkoordinasikan geerakan tubuh dan motorik sejalan dengan perkembangan keterampilan motorik kasar (gross motor skill) dan keterampilan motorik halus (fine motor skill) serta memadukan gerakan keduanya dengan koordinasi ang seimbangan.

Perkembangan

kemampuan mengkoordinasikan gerakan tubuh dan motorik terdiri dari tiga dimensi berikut:
1. Posture, yaitu
kemampuan mengkoordinasikan persepsi visual dan perspsi motorik secara tepat sehingga

${ }^{5}$ Ahmad Susanto, Pendidikan Anak Usia Dini: Konsep dan Teori (Jakarta: Bumi Aksara, 2017), h. 23. 


\begin{tabular}{|l|l|r|}
\hline A1 Fitrah & Pengaruh Permainan Puzzle \\
\hline Journal Of Early Childhood Islamic Education & Magneticeria Terhadap Kecerdasan \\
ISSN $:$ 2599-2287 E-ISSN : 2622-335X & Koordinasi Gerakan Tubuh... \\
Vol.3 No.1Juli 2019 & Sinta Agusmiati \\
\hline
\end{tabular}

individu dapat memposisikan tubuhnya di antara objek-objek di sekitarnya.

2. Laterality, yaitu kemampuan dalam menggerakkan otot dasar dan halus sesuai dengah arah yang dituju.

3. Perpaduan posture dan laterality merupakan prasyarat dalam melakukan koordinasi gerakan tubuh dan otot atau motorik, baik gerakan tubuh yang melibatkan otot kasar, seperti berjalan, melompat, berlari, menarik, mendorong dan lain-lain, maupun gerakan tangan dan jari-jari tangan yang melibatkan koordinasi otot halus, seperti menulis, meronce, memahat, melukis, dan lain-lain.

Anak usia 4-6 tahun telah mampu melakukan koordinasi gerakan tubuh dan motorik kasar dan halus secara seimbang. Di bidang gerakan tubuh yang melibatkan otot kasar, kecerdasan dalam koordinasi gerakan tubuh dan motorik yang tinggi pada usia 4-6 tahun ini dapat diidentifikasi dari kemampuan anak dalam beberapa hal, di antaranya adalah sebagai berikut:

1) Mengendarai sepeda motor roda tiga atau roda dua.

2) Berlari dan berhenti dengan sempurna.

3) Memanjat dan menaiki tangga.

4) Melompat dengan satu kaki atau dua kaki.

5) Meloncat jauh.

6) Berdiri secara seimbang dengan satu kaki.

7) Dapat meniti jembatan atau berjalan di atas balok secara seimbang.

Sementara itu, di bidang gerakan tubuh yang melibatkan otot halus, hal-hal yang dapat dilakukan anak usia 4-6 tahun adalah sebagai berikut:

1) Menggunakan gunting untuk memotong kertas.

2) Memasang dan membuka tali sepatu, kancing, ataupun resleting baju.

3) Menahan kertas dengan satu tangan sementara tangan yang lain digunakan untuk menulis, atau melakukan kegiatan lain.

4) Meronce manik-manik.

5) Melipat kertas untuk dijadikan suatu bentuk.

6) Memasukkan benang ke dalam jarum, dan lain-lain.

Pada tahap yang lebih jauh kemampuan ini terwujud, baik dalam kemampuan menggunakan keseluruhan potensi tubuh untuk mengekpresikan ide-ide dan perasaan (misalnya, sebagai aktor, pantomim, atlit, penari, dan lain-lain), maupun kemampuan menggunakan tangan untuk memproduksi atau mentransformasi suatu benda (misalnya, sebagai pemahat, pelukis, mekanik, ahli bedah, dan lain-lain).

Motorik adalah semua gerakan yang mungkin dapat dilakukan oleh seluruh tubuh yang berhubungan dengan kematangan dan pengendalian gerak tubuh, yaitu: motorik kasar adalah gerakan tubuh yang menggunakan otototot besar atau sebagian besar atau seluruh anggota tubuh yang dipengaruhi oleh kematangan anak itu sendiri; dan motorik halus adalah gerakan yang dilakukan oleh bagianbagian tubuh tertentu dan hanya melibatkan sebagian kecil otot tubuh. ${ }^{6}$

Jhon W. Santrock menjelaskan bahwa keterampilan motorik kasar merupakan keterampilan yang meliputi aktivitas otot yang besar, seperti menggerakkan lengan dan berjalan, sedangkan keterampilan motorik halus melibatkan gerakan yang diatur secara halus, seperti mengancing baju, menggenggam mainan, ataupun keterampilan tangan.

Kemampuan fisik motorik kasar mendeskripsikan gerakan tubuh yang menggunakan otot-otot besar atau sebagian besar atau seluruh anggota tubuh yang dipengaruhi oleh kematangan anak itu sendiri. Pada kemampuan motorik kasar, anak usia dini dapat melakukan gerakan badan secara kasar atau keras seperti merangkak, berjalan, berlari, melompat, melempar, dan berjongkok. Kemampuan fisik motorik halus mendeskripsikan gerakan yang menggunakan otot-otot halus atau sebagian anggota tubuh tertentu yang dipengaruhi oleh kesempatan untuk belajar berlatih. Pada kemampuan motorik halus, anak usia dini dapat melakukan pengkoordinasian gerak tubuh yang melibatkan mata dan tangan untuk dapat melakukan kegiatan yang berhubungan dengan gerakan tangan. Kemampuan motorik halus ini seperti menggenggam, memegang, merobek, menggunting, melipat, mewarnai, menggambar, menulis, menumpuk mainan, dan lainnya. ${ }^{8}$

${ }^{6}$ Richard Decaprio, Panduan Mengembangkan Kecerdasan Motorik Siswa (Yogyakarta: Diva Press, 2017), h. 14.

${ }^{7}$ John W. Santrock, Perkembangan Anak, Penerjemah:Mila Rachmawati (Jakarta: Erlangga, 2007), h. 210-216.

${ }^{8}$ Novan Ardy Wiyani, Konsep Dasar PAUD (Yogyakarta: Gava Media, 2016), h. 111. 


\begin{tabular}{|l|l|r|}
\hline & Al Fitrah & Pengaruh Permainan Puzzle \\
Journal Of Early Childhood Islamic Education & Magneticeria Terhadap Kecerdasan \\
ISSN : 2599-2287 E-ISSN : 2622-335X & Koordinasi Gerakan Tubuh... \\
& Sinta Agusmiati \\
\hline
\end{tabular}

Berikut ini adalah gambaran mengenai tingkat pencapaian perkembangan motorik anak usia dini:

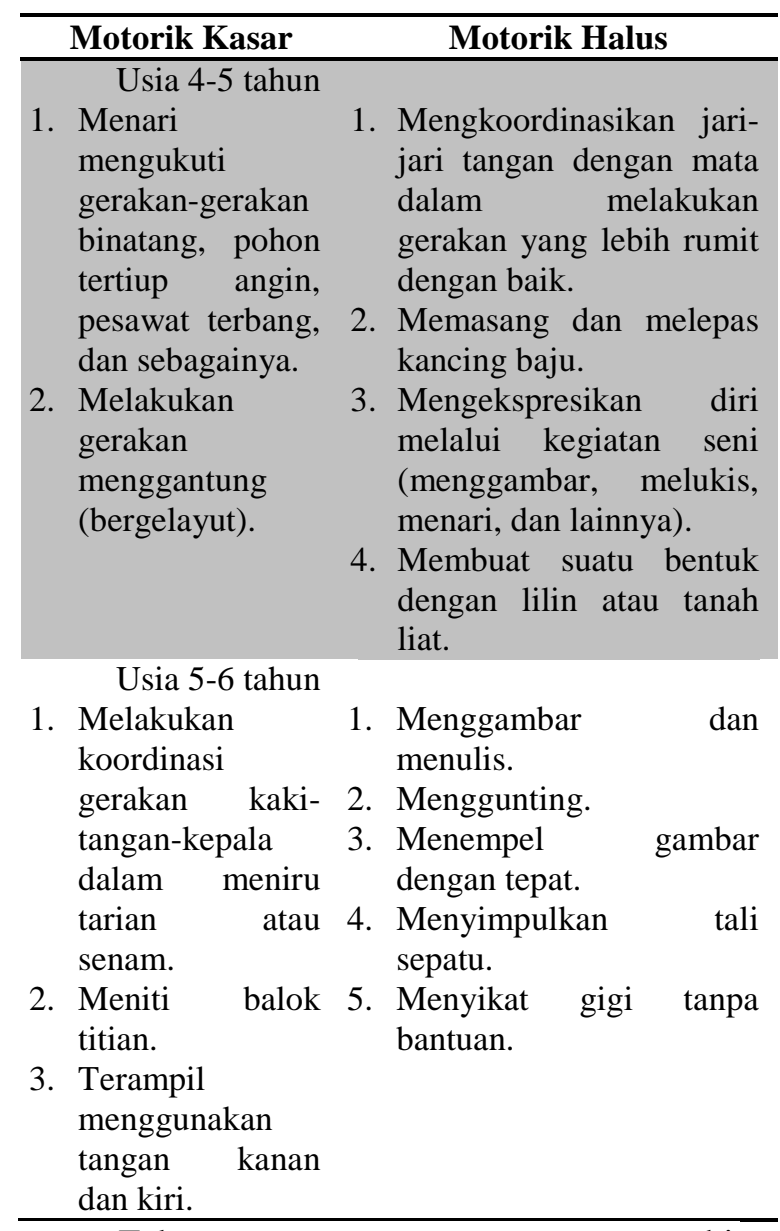

Faktor yang mempengaruhi perkembangan motorik anak adalah faktor hereditas (warisan sejak lahir atau bawaan), faktor lingkungan kematangan fungsi-fungsi organis dan fungsi psikis, serta aktivitas anak sebagai subjek bebas yang berkemauan, berkemampuan, punya emosi serta mempunyai usaha untuk membangun diri sendiri. ${ }^{9}$ Faktorfaktor yang mempengaruhi tinggi rendahnya kualitas pengkembangan anak ditentukan oleh:

1. Faktor internal, yaitu faktor yang berasal dari diri individu itu sendiri yang meliputi pembawaan, potensi, psikologis, semangat belajar serta kemampuan khusus.

2. Faktor eksternal, yaitu faktor yang berasal dari lingkungan luar diri anak baik yang

${ }^{9}$ Richard Decaprio, Panduan Mengembangkan Kecerdasan Motorik Siswa, h. 14. berupa pengalaman teman sebaya, kesehatan dan lingkungan. ${ }^{10}$

Pembelajaran motorik kasar di sekolah merupakan pembelajaran gerakan fisik yang membutuhkan keseimbangan dan kerjasama anggota tubuh, dengan menggunakan otot-otot besar, seperti berlari, berjalan, melompat, memukul, menendang, berlari, dan lain-lain. Sedangkan pembelajaran motorik halus di sekolah ialah pembelajaran yang berhubungan dengan keterampilan fisik yang melibatkan otot kecil serta koordinasi antara mata dan tangan, yang bisa dilatih dan dikembangkan dengan kegiatan dan rangsangan yang dilakukan secara rutin dan terus-menerus, diantaranya:

1. Bermain puzzle;

2. Menyusun balok;

3. Memasukkan benda ke dalam lubang sesuai bentuknya;

4. Membuat garis;

5. Melipat kertas; serta

6. Menulis dengan huruf dan bentuk tulisan yang benar. ${ }^{11}$

Kecerdasan motorik siswa tidaklah sama, dan banyak hal yang mempengaruhi. Di sinilah pentingnya seorang guru dan orang tua dalam mengawasi kehidupan anak di lingkungan sekitarnya. Setiap anak di sekolah dapat mencapai tahapan perkembangan motorik yang optimal, asalkan mendapatkan stimulasi yang tepat dari guru serta lingkungan sekolahnya, sehingga guru dituntut melakukan kegiatan agar anak bisa melewati fase-fase pembelajaran dengan baik dan sempurna. Semakin banyak yang dilihat, didengar, serta dialami oleh anak maka semakin banyak pula yang ingin diketahuinya.

\section{Permainan Puzzle Magneticeria}

Pada umumnya manfaat yang mendidik dari permainan puzzle ialah untuk melatih fokus anak, ketelitian dan kesabaran; melatih keharmonisan atau penyesuaian antara mata dan tangan; melatih logika; memperkuat daya ingat; mengenalkan anak pada konsep hubungan; dengan memilih gambar/bentuk, dapat melatih berfikir matematis (menggunakan otak kiri).

Dalam jurnal internasional Javier Melero mengatakan alasan mengapa puzzle

\footnotetext{
${ }^{10}$ Richard Decaprio, Panduan Mengembangkan Kecerdasan Motorik Siswa, h. 15.

${ }^{11}$ Richard Decaprio, Panduan Mengembangkan Kecerdasan Motorik Siswa, h. 20-21.
} 


\begin{tabular}{|l|l|r|}
\hline A1 Fitrah & Pengaruh Permainan Puzzle \\
\hline Journal Of Early Childhood Islamic Education & Magneticeria Terhadap Kecerdasan \\
ISSN $:$ 2599-2287 E-ISSN : 2622-335X & Koordinasi Gerakan Tubuh... \\
Vol.3 No.1Juli 2019 & Sinta Agusmiati \\
\hline
\end{tabular}

lebih bagus jika dibuat sendiri oleh guru, "There are several reasons that make puzzlebased games interesting approaches to involve teachers as designers. Puzzles usually have simple game rules (simplicity); their rules can be defined independently from content and therefore they can be applied in a wide range of subject matters (generality, independence); and their nature and duration is typically equivalent to other types of learning activities for the classroom or field trips." 12 Ada beberapa alasan yang membuat game berbasis teka-teki lebih menarik jika guru sebagai desainer/pembuat. Teka-teki biasanya memiliki aturan permainan sederhana (kesederhanaan), aturan mereka dapat didefinisikan secara independen dari konten dan karena itu dapat diterapkan dalam berbagai masalah (generalitas, independensi), dan sifat mereka dan durasi biasanya setara dengan jenis kegiatan belajar lainnya untuk kelas atau kunjungan lapangan.

Kegiatan puzzle ini dapat dirangkai dengan potongan jumlah yang sesuai dengan usia anak. Misalnya pada usia 2-3 tahun, potongan puzzle-nya tidak kurang dari 4 biji; usia 3-4 tahun potongan puzzle-nya tidak lebih dari 5 biji, untuk anak TK 4-5 tahun potongan puzzle-nya tidak lebih dari enam biji dan untuk SD ke atas potongan puzzle-nya tidak lebih dari tujuh biji. Seperti sentra-sentra lainnya sentra puzzle pun bisa dikemas sedemikian rupa, oleh karena itu semua kecerdasan anak terealisasikan dengan baik. Misalnya di puzzle tersebut diberi gambar orang yang sedang solat (untuk mencerdaskan daya spiritualisasinya anak), dimainkan oleh dua anak (untuk mengasah daya emosi-sosial dan interpersonal), jika permainan puzzle ini jika dilakukan oleh anak-anak maka akan mengasah daya kompetitif anak dan lainlain.

Berdasarkan beberapa alasan atau problem di atas, penulis mempunyai gagasan untuk menciptakan sebuah permainan yang dapat membuat anak bermain sekaligus mengembangkan kecerdasannya, yaitu melalui permainan puzzle persegi yang memakai magnet. Permainan ini diharapkan dapat menjadi alternatif permainan anak yang edukatif dan bermanfaat. Permainan puzzle

\footnotetext{
${ }^{12}$ Javier Melero and Davinia Hernandez-Leo, ”A Model for Design of Puzzle-based Games Including Virtual and Physical Objects,” Educational Technology \& Society, 17 (3), 192-207.
}

magneticeria bertujuan mengembangkan kecerdasan jamak diantaranya adalah kecerdasan verbal linguistik, kecerdasan logika matematika, kecerdasan visual spasial, kecerdasan koordinasi gerakan tubuh dan motorik, dan kecerdasan interpersonal.

Permainan puzzle magneticeria adalah puzzle bergambar dengan bentuk persegi yang memakai magnet sebagai alat untuk menempelkan bagian kotak dengan papan puzzle, yang akan membuat anak usia dini ceria karena keunikan dan perbedaannya dengan puzzle biasa yang dijual di toko mainan. Puzzle magneticeria ini diperuntukkan anak usia dini dengan rentang usia 5-6 tahun, dimana permainan ini dapat meningkatkan perkembangan kecerdasan jamak anak, yaitu anak dapat bermain dan menempel gambar dengan tepat sesuai dengan masa perkembangannya.

Peneliti mengutip tujuan dari permainan puzzle, yaitu:

1. Menumbuhkan rasa kebersamaan antar anak. Jika ada permainan dalam satu kelompok, maka kebersamaan dalam satu kelompok akan tumbuh.

2. Melatih strategi dalam satu kelompok. Untuk merampungkan permainan puzzle, maka ada strategi yang harus digunakan. Dengan adanya kebersamaan dalam kelompok, strategi permainan ini akan mudah terpecahkan.

3. Melatih memecahkan masalah bersamasama. Jika permainan dilakukan dengan bekerja kelompok, maka akan mudah menyelesaikan permainan puzzle ini.

4. Menumbuhkan saling memiliki di antara anak. Setiap anak akan merasa memiliki jika bekerja sama dalam kelompok.

5. Menumbuhkan sikap saling menghargai sesama anak. Dalam permainan kelompok, pasti setiap anak memiliki gagasan untuk memecahkan masalah, namun ketika kerja kelompok, mereka harus bisa menghargai pendapat orang lain.

6. Menghibur para siswa di dalam kelas. Permainan menjadi salah satu media penghibur siswa di sela-sela penerimaan materi belajar. ${ }^{13}$

\footnotetext{
${ }^{13}$ Aurelia Prima, Aneka Permainan Kreatif dan Edukatif untuk Anak (Yogyakarta: Diva Press, 2016), h. 111-112.
} 


\begin{tabular}{|l|l|r|}
\hline & Al Fitrah & Pengaruh Permainan Puzzle \\
Journal Of Early Childhood Islamic Education & Magneticeria Terhadap Kecerdasan \\
ISSN : 2599-2287 E-ISSN : 2622-335X & Koordinasi Gerakan Tubuh... \\
Vol.3 No.1Juli 2019 & Sinta Agusmiati \\
\hline
\end{tabular}

Begitu juga dengan puzzle magneticeria ini, tujuan yang ingin dicapai adalah:

1. Menarik minat anak dalam belajar dengan bermain.

2. Menumbuhkan rasa kebersamaan antar anak. Jika ada permainan dalam satu kelompok, maka kebersamaan dalam satu kelompok akan tumbuh.

3. Melatih strategi dalam satu kelompok. Untuk merampungkan permainan puzzle, maka ada strategi yang harus digunakan. Melatih memecahkan masalah bersamasama. Jika permainan dilakukan dengan bekerja kelompok, maka akan mudah menyelesaikan permainan puzzle ini.

4. Menumbuhkan saling memiliki di antara anak. Setiap anak akan merasa memiliki jika bekerja sama dalam kelompok.

5. Menumbuhkan sikap saling menghargai sesama anak.

6. Menghibur para siswa di dalam kelas. Permainan menjadi salah satu media penghibur siswa di sela-sela penerimaan materi belajar.

7. Jika guru membuat puzzle magneticeria dengan berbagai tema, akan membuat permainan ini sebagai media pembelajaran.

Manfaat dari puzzle magneticeria sama seperti tujuan dibuatnya puzzle, hanya berbeda bentuk dan permainan ini dikhususkan untuk berkelompok. Puzzle magneticeria juga menggunakan prinsip belajar melalui bermain, dimana dengan bermain dapat membantu anak mengembangkan potensi dan bisa diajak bereksplorasi, menemukan, dan memanfaatkan objek-objek yang dekat dengan anak, sehingga pembelajaran menjadi bermakna bagi anak.

\section{Metode Penelitian}

Jenis penelitian yang digunakan penulis yaitu penelitian pre-eksperimental design, yaitu salah satu bentuk desain eksperimen yang belum merupakan eksperimen sungguhsumgguh karena masih terdapat variabel luar yang ikut berpengaruh terhadap terbentuknya variabel dependen. ${ }^{14}$ Metode eksperimen (eksperimental reaserch) dapat diartikan sebagai metode penelitian yang digunakan untuk mencari pengaruh suatu perlakuan

\footnotetext{
${ }^{14}$ Sugiyono, Metode Penelitian Kuantitatif, Kualitatif, dan R\&D (Bandung: Alfabeta, 2016), h. 74.
}

tertentu terhadap yang lain dalam kondisi yang terkendalikan.

Teknik analisis data dalam penelitian ini yang digunakan adalah run test, yaitu untuk menguji hipotesis deskriptif (satu sampel), bila skala pengukurannya ordinal maka run test dapat digunakan untuk mengukur urutan suatu kejadian. Pengujian dilakukan dengan cara mengukur ke-random-an populasi yang didasarkan atas data hasil pengamatan melalui data sampel. Jika jumlah sampel $\leq 40$, maka menggunakan aturan tabel-tabel harga kritis $\mathrm{r}$ dalam test run, $a=5 \%$ dan jika sampel $>40$. Subjek dari peeneitian ini adalah anak usia dini kelas B PAUD KArya Galang Selebar Kota Bengkulu yang berjumlah 14 anak dengan menggunakan permainan puzzle magneticeria.

\section{Hasil Penelitian}

Adapun hasil peneitian yang telah peneliti lakukan di PAUD Karya Galang Selebar Kota Bengkulu, dengan data skor anak pada post-treatment diurutkan dari skor terkecil, yaitu:

$\begin{array}{llllll}86 & 88 & 94 & 96 & 989898 & 100100100\end{array}$ 104104104104

Ha : Terdapat pengaruh permainan puzzle magneticeria terhadap kecerdasan koordinasi gerakan tubuh dan motorik anak di PAUD Karya Galang Selebar Kota Bengkulu.

Ho : Tidak terdapat pengaruh permainan puzzle magneticeria terhadap kecerdasan koordinasi gerakan tubuh dan motorik anak di PAUD Karya Galang Selebar Kota Bengkulu.

Jumlah anak dalam penelitian adalah 14 anak. Pada data di atas terdapat jumlah run $=7$. Taraf kesalahan ditetapkan 5\%. Adapun perhitungan dalam run test, yaitu:

$$
\begin{aligned}
\mu_{\mathrm{r}} & =\frac{2 \cdot 7 \cdot 7}{7+7}+1-0,5 \\
& =\frac{98}{14}+1-0,5 \\
& =7+1-0,5=7,5 \\
\sigma_{\mathrm{r}} & =\underline{\sqrt{ } 2 \cdot 7 \cdot 7 \cdot(2 \cdot 7 \cdot 7-7-7)}
\end{aligned}
$$




\begin{tabular}{|l|l|r|}
\hline & Al Fitrah & Pengaruh Permainan Puzzle \\
Journal Of Early Childhood Islamic Education & Magneticeria Terhadap Kecerdasan \\
ISSN : 2599-2287 E-ISSN : 2622-335X & Koordinasi Gerakan Tubuh... \\
Vol.3 No.1Juli 2019 & Sinta Agusmiati \\
\hline
\end{tabular}

$$
\begin{aligned}
& \sqrt{ }(7+7)^{2} \cdot(7+7-1) \\
\sigma_{\mathrm{r}}= & \frac{\sqrt{98.84}}{\sqrt{ } 196.13} \\
= & \frac{\sqrt{8232}}{\sqrt{2548}} \\
= & \frac{90,73}{50,48}=1,8 \\
= & \frac{\mathrm{r}-\mu_{\mathrm{r}}}{\sigma \mathrm{r}} \\
= & \frac{7-7,5}{1,8} \\
= & \frac{0,5}{1,8} \\
\mathrm{z}= & 0,28
\end{aligned}
$$

Berdasarkan harga $\mathrm{z}_{\mathrm{hitung}}=0,28$, maka harga $\mathrm{z}_{\text {tabel }}$ adalah 0,3897 . Harga ini ternyata lebih besar dari harga $\alpha$ yang ditetapkan 5\% atau 0,05 $(0,3897>0,05)$. Hal ini berarti Ha diterima dan Ho ditolak, artinya terdapat pengaruh permainan puzzle magneticeria terhadap kecerdasan koordinasi gerakan tubuh dan motorik anak di PAUD Karya Galang Selebar Kota Bengkulu.

\section{Pembahasan}

Pendidikan Anak Usia Dini adalah suatu usaha pembinaan yang ditujukan kepada anak sejak lahir sampai dengan usia enam tahun yang dilakukan melalui pemberian rangsangan pendidikan untuk membantu pertumbuhan dan perkembangan jasmani dan rohani agar anak memiliki kesiapan dalam memasuki pendidikan lebih lanjut. Anak usia dini adalah anak yang baru dilahirkan sampai usia 6 tahun, merupakan usia yang sangat menentukan dalam pembentukan karakter dan kepribadian anak, usia dini merupakan usia yang mana anak mengalami pertumbuhan dan perkembangan yang pesat, disebut usia emas (golden age), makanan bergizi seimbang serta asupan yang terus menerus sangat dibutuhkan untuk tumbuh kembang anak.

Berdasarkan tinjauan secara psikologi dan ilmu pendidikan, masa usia dini merupakan masa peletak dasar atau fondasi awal bagi pertumbuhan dan perkembangan anak, yang diterima anak pada masa usia dini, baik itu makanan, minuman, serta stimulasi dari lingkungannya memberikan kontribusi yang sangat besar pada pertumbuhan dan perkembangan anak pada masa itu dan berpengaruh besar pertumbuhan serta perkembangan selanjutnya. Hal inilah yang menjadi kewajiban pemerintah untuk melaksanakan pendidikan anak usia dini, karena sangat penting untuk masa depan anak bangsa. Tujuan dari diselenggarakannya PAUD, yaitu secara umum adalah mengembangkan berbagai potensi anak sejak dini sebagai persiapan untuk hidup dan dapat menyesuaikan diri dengan lingkungannya, dengan tujuan utama ialah untuk membentuk anak Indonesia yang berkualitas, yaitu anak yang tumbuh dan berkembang sesuai dengan tingkat perkembangannya sehingga memiliki kesiapan yang optimal di dalam memasuki pendidikan dasar serta mengarungi kehidupan di masa dewasa, juga tujuan penyerta membantu menyiapkan anak mencapai hasil belajar akademik di sekolah. Tujuan khusus yang ingin dicapai adalah mengidentifikasi perkembangan tubuh anak dan mengaplikasikan hasilnya dalam pengembangan fisik anak itu; paham perkembangan kreativitas anak dan cara yang terkait dengan pengembangannya; memahami kecerdasan jamak dan kaitannya dengan perkembangan anak; mengerti arti bermain untuk perkembangan anak; memahami pendekatan pembelajaran dan penerapannya; membantu kesiapan anak belajar di sekolah; campur tangan guru da orang tua memberikan stimulasi hingga dapat menumbuhkan bakat yang tersembunyi (hidden potency) yaitu perkembangan anak (bahasa, emosi, sosial, motorik, konsep diri, minat dan bakat); melakukan deteksi dini terhadap kemungkinan terjadinya gangguan dalam pertumbuhan dan perkembangan potensi-potensi yang dimiliki anak.

Dunia anak adalah dunia bermain, oleh karena itu para ahli menawarkan konsep belajar sambil bermain dan bermain sambil belajar. Dengan memadukan antara keduanya, maka esensi belajar tetap ada dalam permainan anak, dan anak juga tidak diasingkan dari dunia bermainnya. Bermain bermanfaat bagi perkembangan fisik atau motorik, 


\begin{tabular}{|l|l|r|}
\hline & Al Fitrah & Pengaruh Permainan Puzzle \\
Journal Of Early Childhood Islamic Education & Magneticeria Terhadap Kecerdasan \\
ISSN : 2599-2287 E-ISSN : 2622-335X & Koordinasi Gerakan Tubuh... \\
& Sol.3 No.1Juli 2019 & Sinta Agusmiati \\
\hline
\end{tabular}

perkembangan kognitif, perkembangan afektif, serta perkembangan sosial emosional anak.

Pada saat observasi awal, peneliti mewawancarai guru dan kepala sekolah di PAUD Karya Galang, ditemukan permasalahan yaitu terbatasnya jumlah guru yang mengajar, anak kurang terkontrol saat belajar, ada anak yang selalu menguasai kelas, model pembelajaran yang digunakan belum bervariasi, alat permainan edukatif hanya digunakan pada saat anak istirahat, media pembelajaran hanya sebatas buku untuk menggambar dan pletisin, permainan edukatif yang dimiliki PAUD adalah buatan pabrik, anak sudah memiliki di rumah, sehingga anak menjadi jenuh, bosan dan tidak tertarik lagi saat bermain di sekolah. Oleh sebab itu, peneliti menggunakan media pembelajaran baru yaitu alat permainan edukatif buatan sendiri, agar anak lebih tertarik dalam pembelajaran.

Dalam pelaksanaan pembelajaran, tugas utama seorang guru adalah mengajar, mendidik dan melatih siswa mencapai taraf kecerdasan, ketinggian budi pekerti, dan keterampilan yang optimal. Pembelajaran yang berkualitas adalah pembelajaran yang mampu meletakkan posisi guru dengan tepat sehingga guru dapat memainkan perannya sesuai dengan kebutuhan peserta didik. Sebagai fasilitator, guru tidaklah mengajar, tetapi melayani peserta didik untuk belajar; sebagai motivator, guru mendorong peserta didik untuk belajar; sebagai pemacu, guru menyentuh faktor-faktor belajar agar kompetensi peserta didik meningkat; sebagai perekayasa, guru memanfaatkan segala media dan sumber belajar agar peserta didik mencapai kompetensi yang telah ditentukan; sebagai pemberi inspirasi, guru mengubah pandanan dan kehidupan peserta didik menjadi lebih baik.

Dalam pembelajaran, guru juga berfungsi sebagai mediator, yang dapat diartikan sebagai penengah dalam kegiatan belajar mengajar, misalnya menengahi atau memberikan jalan keluar dalam kegiatan diskusi siswa, dan dapat juga diartikan sebagai penyedia media yang mengetahui bagaimana memakai dan mengorganisasikan penggunaan media. Jadi, kompetensi yang harus dimiliki oleh guru sebagai perekayasa pembelajaran ialah mampu menyusun desain pembelajaran dan mengaplikasikannya dengan memanfaatkan berbagai macam sumber dan media agar peserta didik mencapai kompetensi yang telah ditentukan.

Banyak manfaat bermain bagi perkembangan anak, seperti: anak menguasai berbagai konsep dasar di dalam pembelajaran, mengembangkan kreativitas anak, memberikan pengalaman kepada anak untuk bereksplorasi, memberi kepuasan kepada anak untuk menciptakan sesuatu. Kreativitas anak dapat terasah dengan bermain yang perwujudannnya melalui pengembangan berbagai potensi yang dimiliki oleh seorang anak. Pengalaman juga dapat diperoleh dengan menjelajahi lingkungan sekitarnya sehingga rasa keingintahuan anak dapat terpenuhi dan anak dapat bereksplorasi menemukan dan memanfaatkan objek-objek yang dekat dengannya, sehingga pembelajaran menjadi lebih bermakna. Anak juga dapat menciptakan sesuatu dengan bermain, seperti membuat karya hasil ciptaannya sendiri. Bermain juga dapat memberi kepuasan kepada anak untuk menciptakan sesuatu, sehingga diperoleh hasil karya yang menarik dan sesuai dengan karakter yang dimilki masing-masing anak. Selain itu, bermain bagi anak merupakan proses kreatif, dapat menggunakan simbol untuk menggambarkan dunianya dan dapat membangun pengertian yang berkaitan dengan pengalamannya. Bermain juga berguna sebagai sarana mengembangkan dan meningkatkan keterampilan serta kemampuan tertentu pada anak. Artinya dengan bermain dapat mengembangkan potensi perkembangan kognitif yang dimiliki siswa.

Permainan puzzle magneticeria adalah puzzle bergambar dengan bentuk persegi yang memakai magnet sebagai alat untuk menempelkan bagian kotak dengan papan puzzle, yang akan membuat anak usia dini ceria karena keunikan dan perbedaannya dengan puzzle biasa yang dijual di toko mainan. Puzzle magneticeria ini diperuntukkan anak usia dini dengan rentang usia 5-6 tahun, permainan ini dapat meningkatkan perkembangan kecerdasan jamak anak, yaitu anak dapat bermain dan menempel gambar dengan tepat sesuai dengan masa perkembangannya. Tujuan dari permainan puzzle, yaitu: menumbuhkan rasa kebersamaan antar anak, jika ada permainan dalam satu kelompok, maka kebersamaan dalam satu kelompok akan tumbuh; melatih strategi dalam satu kelompok, untuk merampungkan permainan puzzle, maka ada strategi yang harus 


\begin{tabular}{|l|l|r|}
\hline A1 Fitrah & Pengaruh Permainan Puzzle \\
\hline Journal Of Early Childhood Islamic Education & Magneticeria Terhadap Kecerdasan \\
ISSN $:$ 2599-2287 E-ISSN : 2622-335X & Koordinasi Gerakan Tubuh... \\
Vol.3 No.1Juli 2019 & Sinta Agusmiati \\
\hline
\end{tabular}

digunakan, dengan adanya kebersamaan dalam kelompok, strategi permainan ini akan mudah terpecahkan; melatih memecahkan masalah bersama-sama, jika permainan dilakukan dengan bekerja kelompok, maka akan mudah menyelesaikan permainan puzzle ini; menumbuhkan saling memiliki di antara anak, setiap anak akan merasa memiliki jika bekerja sama dalam kelompok; menumbuhkan sikap saling menghargai sesama anak, dalam permainan kelompok, pasti setiap anak memiliki gagasan untuk memecahkan masalah, namun ketika kerja kelompok, mereka harus bisa menghargai pendapat orang lain; menghibur para siswa di dalam kelas. Permainan menjadi salah satu media penghibur siswa di sela-sela penerimaan materi belajar.

Begitu juga dengan puzzle magneticeria ini, tujuan yang ingin dicapai adalah: menarik minat anak dalam belajar dengan bermain; menumbuhkan rasa kebersamaan antar anak. Jika ada permainan dalam satu kelompok, maka kebersamaan dalam satu kelompok akan tumbuh; melatih strategi dalam satu kelompok, untuk merampungkan permainan puzzle, maka ada strategi yang harus digunakan, jika permainan dilakukan dengan bekerja kelompok, maka akan mudah menyelesaikan permainan puzzle ini; menumbuhkan saling memiliki di antara anak. Setiap anak akan merasa memiliki jika bekerja sama dalam kelompok; menumbuhkan sikap saling menghargai sesama anak; menghibur para siswa di dalam kelas. Permainan menjadi salah satu media penghibur siswa di sela-sela penerimaan materi belajar; jika guru membuat puzzle magneticeria dengan berbagai tema, akan membuat permainan ini sebagai media pembelajaran. Manfaat dari puzzle magneticeria sama seperti tujuan dibuatnya puzzle, hanya berbeda bentuk dan permainan ini dikhususkan untuk berkelompok. Puzzle magneticeria juga menggunakan prinsip belajar melalui bermain, dimana dengan bermain dapat membantu anak mengembangkan potensi dan bisa diajak bereksplorasi, menemukan, dan memanfaatkan objek-objek yang dekat dengan anak, sehingga pembelajaran menjadi bermakna bagi anak.

Langkah-langkah dari permainan puzzle magneticeria, ialah: guru membuat puzzle sesuai dengan tema yang akan diajarkan kepada anak; guru membuat kelompok anak sesuai dengan jumlah puzzle yg ada; tiap kelompok diberi satu puzzle yang terdiri dari papan gambar hitam putih dan potongan gambar puzzle; guru menyampaikan tujuan dari tema dan permainan puzzle magneticeria yang akan dimainkan; guru menjelaskan arti dari gambar dan tulisan yang ada di puzzle magneticeria agar kecerdasan anak berkembang; guru menempelkan papan bergambar ke papan tulis, agar anak dapat berjalan untuk menempelkan potongan puzzle untuk meningkatkan motorik kasarnya; guru menghitung dari 1 sampai 3 tanda permainan dimulai; tiap anak diminta maju satu persatu untuk menempelkan potongan gambar puzzle ke papan gambar hitam putih yang telah tersedia, sedangkan anak lainnya memberikan semangat; pemenang permainan ini adalah kelompok yang berhasil menyusun gambar utuh dengan cepat; guru mengakhiri permainan ini dengan ceria, yaitu tepuk tangan dan bernyanyi bersama, agar suasana kelas makin ceria.

Kecerdasan jamak (multiple intelligences) adalah sebuah penilaian yang melihat secara deskritif bagaimana individu menggunakan kecerdasannya untuk memecahkan masalah dan menghasilkan sesuatu. Pendekatan ini merupakan alat untuk melihat bagaimana pikiran manuia mengoperasikan dunia, baik itu benda-benda yang konkret maupun hal-hal yang abstrak, karena tidak ada anak yang bodoh atau pintar, yang ada anak yang menonjol dalam salah satu atau beberapa jenis kecerdasan.

Inteligensi berkaitan dengan kemampuan manusia dalam berpikir, dengan kata lain, inteligensi merupakan aktivitas mental. Kecerdasan atau inteligensi merupakan aktivitas mental yang diarahkan pada kegiatan yang bertujuan untuk menyesuaikan diri, memilih, dan membentuk lingkungan yang sesuai dengan kehidupan individu, inteligensi adalah hasil interaksi aktif antara kemampuan yang dibawa sejak lahir dengan berbagai pengalaman yang diperoleh dari lingkungan yang menghasilkan kemampuan individu untuk mengingat, mengerti makna dari konsep kongkrit dan konsep abstrak, memahami hubungan-hubungan antara objek, peristiwa, dan ide, serta kemampuan dalam menerapkan semua hal tersebut untuk memecahkan berbagai masalah yang dihadapi. Kecerdasan bukanlah merupakan sesuatu yang bersifat tunggal akan tetapi bersifat lebih dari satu kecerdasan, yang 


\begin{tabular}{|l|l|r|}
\hline & Al Fitrah & Pengaruh Permainan Puzzle \\
Journal Of Early Childhood Islamic Education & Magneticeria Terhadap Kecerdasan \\
ISSN : 2599-2287 E-ISSN : 2622-335X & Koordinasi Gerakan Tubuh... \\
& Sinta Agusmiati \\
\hline
\end{tabular}

disebut dengan multiple intelligences atau kecerdasan jamak.

Menurut teori multiple intelligences, kecerdasan ini tidak berkembang dalam ruang hampa, tetapi harus dimobilitasi dalam berbagai aktivitas yang berkelanjutan dalam suatu budaya di mana individu merasa memiliki arti praktis dan konsekuensi nyata. Delapan kecerdasan yang dimaksud ialah: linguistic (linguistik); spatial (visual spasial); interpersonal (interpersonal); intrapersonal (intrapersonal): logical-mathematical (logika matematika); musical (musikal); naturalist (natural); bodily-kinesthetic (fisik).

Kecerdasan koordinasi gerakan tubuh dan motorik, yaitu kepekaan dan keterampilan dalam mengontrol koordinasi gerakan tubuh melalui gerakan motorik kasar dan halus. Perkembangan kemampuan mengkoordinasikan geraakan tubuh dan motorik terdiri dari tiga dimensi: posture, yaitu kemampuan mengkoordinasikan persepsi visual dan persepsi motorik secara tepat sehingga individu dapat memposisikan tubuhnya di antara objek-objek di sekitarnya; laterality, yaitu kemampuan dalam menggerakkan otot kasar dan halus sesuai dengan arah yang dituju; dan perpaduan posture dan literality yang merupakan prasyarat dalam melakukan koordinasi gerakan tubuh dan otot atau motorik, baik otot kasar maupun otot halus. Di bidang gerakan tubuh yang melibatkan otot kasar, kecerdasan koordinasi gerakan tubuh dan motorik anak usia 4-6 tahun dapat diidentifikasi dari kemampuannya dalam: mengendarai sepeda roda tiga atau roda dua, berlari dan berhenti dengan sempurna, memanjat, menaiki tangga, melompat dengan satu kaki, dan dapat meniti jembatan atau berjalan di atas balok secara seimbang. Di bidang gerakan otot halus, anak seusia ini sudah mampu: menggunakan gunting untuk memotong kertas; memasang dan membuka tali sepatu, kancing atau resleting baju; menahan kertas dengan satu tangan sementara tangan yang lain digunakan untuk menulis atau kegiatan yang lain; meronce manik-manik; melipat kertas untuk dijadikan suatu bentuk; serta memasukkan benang ke dalam jarum.

Dalam penelitian ini, kecerdasan gerakan tubuh dan motorik anak ditingkatkan dengan guru meminta anak menempelkan kepingan puzzle magneticeria ke papan puzzle yang ada di papan tulis. Gerakan ini dapat meningkatkan kemampuan motoric kasar anak seperti berjalan dan motorik halus anak yaitu mencocokkan kepingan puzzle magneticeria.

Berdasarkan harga $\mathrm{z}_{\text {hitung }}=0,28$, maka harga $\mathrm{z}_{\text {tabel }}$ adalah 0,3897 . Harga ini ternyata lebih besar dari harga $\alpha$ yang ditetapkan $5 \%$ atau 0,05 $(0,3897>0,05)$. Hal ini berarti Ha diterima dan Ho ditolak, artinya terdapat pengaruh permainan puzzle magneticeria terhadap kecerdasan koordinasi gerakan tubuh dan motorik anak di PAUD Karya Galang Selebar Kota Bengkulu.

\section{Daftar Pustaka}

Arikunto, Suharsimi. 2013. Manajemen Penelitian. Jakarta: Rineka Cipta.

Aziz, Safrudin. 2017. Strategi Pembelajaran Aktif Anak Usia Dini. Yogyakarta: Kali Media.

Decaprio, Richard. 2017. Panduan Mengembangkan Kecerdasan Motorik Siswa. Yogyakarta: Diva Press.

Hasan, Maimunah. 2010. PAUD: Pendidikan Anak Usia Dini. Jogjakarta: Diva Press.

Hasnida. 2016. Panduan Pendidik dalam Mengimplementasikan Kurikulum PAUD 2013. Jakarta: Luxima Metro Media.

Lalompoh, Cyrus T. dan Kartini Ester. 2017. Metode Pengembangan Moral dan Nilai-Nilai Keagamaan bagi Anak Usia Dini. Jakarta: Grasindo.

Melero, Javier and Davinia Hernandez-Leo. 2013. A Model for Design of Puzzlebased Games Including Virtual and Physical Objects. Educational Technology \& Society, 17 (3).

Mulyani, Novi. 2016. Dasar-Dasar Pendidikan Anak Usia Dini. Yogyakarta: Kalimedia.

Prima, Aurelia. 2016. Aneka Permainan Kreatif dan Edukatif untuk Anak. Yogyakarta: Diva Press.

Santoso, Singgih. 2012. Aplikasi SPSS pada Statistik Parametrik. Jakarta: Elex Media Komputindo. 


\begin{tabular}{|l|l|r|}
\hline Al Fitrah & Pengaruh Permainan Puzzle \\
Journal Of Early Childhood Islamic Education & Magneticeria Terhadap Kecerdasan \\
ISSN $:$ 2599-2287 E-ISSN : 2622-335X & Koordinasi Gerakan Tubuh... \\
Vol.3 No.1Juli 2019 & Sinta Agusmiati \\
\hline
\end{tabular}

Santrock, John W. 2007. Perkembangan

Anak, Penerjemah: Mila

Rachmawati. Jakarta: Erlangga.

Sugiyono. 2016. Metode Penelitian

Kuantitatif, Kualitatif, dan $R \& D$.

Bandung: Alfabeta.

Sugiyono. 2017. Statistika untuk Penelitian.

Bandung: Alfabeta.

Sujiono, Yuliani Nurani dan Bambang

Sujiono. 2010. Bermain Kreatif

Berbasis Kecerdasan Jamak.

Jakarta: Indeks.

Susanto, Ahmad. 2017. Pendidikan Anak Usia Dini: Konsep dan Teori. Jakarta: Bumi Aksara.

Tim Pustaka Yustisia. 2013. Perundangan tentang Kurikulum Sistem Pendidikan Nasional Nomor 20 Tahun 2013. Yogyakarta: Pustaka Yustisia.

Wiyani, Novan Ardy. 2015. Manajemen PAUD Bermutu. Yogyakarta: Gava Media.

Wiyani, Novan Ardy. 2016. Konsep Dasar PAUD. Yogyakarta: Gava Media. 